\title{
Effects of Tacrolimus (FK506) on Human Insulin Gene Expression, Insulin mRNA Levels, and Insulin Secretion in HIT-T15 Cells
}

\author{
J. Bruce Redmon, ${ }^{\star}$ L. Karl Olson, ${ }^{\ddagger}$ Michael B. Armstrong, ${ }^{\star}$ Michael J. Greene, ${ }^{\star}$ and R. Paul Robertson* \\ *Division of Diabetes, Endocrinology, and Metabolism, Department of Medicine, University of Minnesota, Minneapolis, Minnesota \\ 55455; and ${ }^{\ddagger}$ Department of Physiology, Michigan State University, East Lansing, Michigan 48824
}

\begin{abstract}
FK506 (tacrolimus) is an immunosuppressive drug which interrupts $\mathrm{Ca}^{2+}$-calmodulin-calcineurin signaling pathways in $\mathrm{T}$ lymphocytes, thereby blocking antigen activation of $\mathrm{T}$ cell early activation genes. Regulation of insulin gene expression in the $\beta$ cell may also involve $\mathrm{Ca}^{2+}$-signaling pathways and FK506 has been associated with insulin-requiring diabetes mellitus during clinical use. The purpose of this study was to characterize the effects of FK506 on human insulin gene transcription, insulin mRNA levels, and insulin secretion using as a model the HIT-T15 $\beta$ cell line. FK506 had no acute effect on insulin secretion in the HIT cell, but caused a reversible time- and dose-dependent $\left(10^{-9}-10^{-6} \mathrm{M}\right)$ decrease in HIT cell insulin secretion. Decreased insulin secretion in the presence of FK506 was also accompanied by a dosedependent decrease in HIT cell insulin content, insulin mRNA levels, and expression of a human insulin promoterchloramphenicol acetyl transferase (CAT) reporter gene. FK506 decreased HIT cell expression of the human insulin promoter-CAT reporter gene by $40 \%$ in the presence of both low $(0.4 \mathrm{mM})$ at high $(20 \mathrm{mM})$ glucose concentrations. Western blot analysis of HIT cell proteins gave evidence for the presence of calcineurin in the HIT cell. These findings suggest that FK506 may have direct effects to reversibly inhibit insulin gene transcription, leading to a decline in insulin mRNA levels, insulin synthesis, and ultimately insulin secretion. (J. Clin. Invest. 1996. 98:2786-2793.) Key words: diabetes mellitus $\bullet$ calcium $\cdot$ cyclosporine $\cdot$ glucose $\bullet$ transcription
\end{abstract}

\section{Introduction}

Insulin gene expression and insulin secretion appear to be coordinately regulated in the $\beta$ cell: metabolic, neural, or hormonal signals that increase or decrease insulin secretion often have analogous effects on expression of the insulin gene (1-10).

Address correspondence to J. Bruce Redmon, Division of Diabetes, Endocrinology, and Metabolism, Box 101, UMHC, University of Minnesota, Minneapolis, MN 55455. Phone: 612-626-1960; FAX: 612626-3133; E-mail: Redmo001@maroon.tc.umn.edu.

Michael J. Greene's current address is Department of Zoology, Oregon State University, Corvallis, OR 97331.

Received for publication 4 December 1995 and accepted in revised form 17 October 1996.

J. Clin. Invest.

(c) The American Society for Clinical Investigation, Inc. 0021-9738/96/12/2786/08 \$2.00

Volume 98, Number 12, December 1996, 2786-2793
For example, changes in the level of extracellular glucose, the most important regulator of insulin secretion, produce concomitant changes in the level of insulin gene expression and ultimately the rate of insulin synthesis (1-6).

The cellular mechanisms that translate changes in extracellular glucose or other signals into changes in the rate of insulin release have been extensively studied. Relatively little is known, however, about the cellular mechanisms that regulate insulin gene expression $(1,11)$. Potential mediators involved in regulation of insulin gene transcription include $\mathrm{Ca}^{2+}, \mathrm{cAMP}$, and phosphoinositide/protein kinase $\mathrm{C}$ signaling pathways (1, $6,12-14) . \mathrm{Ca}^{2+}$-dependent second messenger pathways, in particular, have been proposed to play a key role in insulin gene regulation $(6,12)$, although this remains an area of active debate $(13,14)$.

FK506 (tacrolimus) is an immunosuppressive drug that acts in part by blocking antigen-stimulated expression of the interleukin-2 gene and other early activation genes in T cells (15-17). Antigen activation of $\mathrm{T}$ cells is a $\mathrm{Ca}^{2+}$-mediated process that involves $\mathrm{Ca}^{2+} /$ calmodulin activation of a serine/threonine phosphatase, calcineurin. FK506 and the structurally unrelated drug cyclosporin A block $\mathrm{Ca}^{2+}$-mediated interleukin-2 gene transcription by preventing $\mathrm{Ca}^{2+} /$ calmodulin activation of calcineurin (18).

Use of FK506 in human organ transplantation has been associated with a $10-30 \%$ incidence of diabetes mellitus and FK506 and cyclosporin A have recently been reported to decrease insulin mRNA levels in studies using rat islets or insulin-secreting tumor cell lines (19-24). These observations suggest that FK506 may have direct effects to inhibit insulin gene transcription. We, therefore, studied effects of FK506 on insulin secretion, synthesis, and human insulin gene expression in the HIT cell, a glucose-responsive, insulin-secreting islet cell line (25).

\section{Methods}

Cell culture. HIT-T15 cells between passages 65 and 80 were routinely grown in $5 \% \mathrm{CO}_{2} / 95 \%$ humidified air at $37^{\circ} \mathrm{C}$, maintained in RPMI-1640 medium containing $11.1 \mathrm{mM}$ glucose and $10 \%$ fetal calf serum.

Insulin secretion and cellular insulin content. For static insulin secretion experiments, $1 \times 10^{6} \mathrm{HIT}$ cells/well were plated in 12-well plates and grown for varying periods of time in culture medium supplemented with vehicle only (ethanol) or FK506. Static incubations were carried out in the absence of FK506 or vehicle for $4 \mathrm{~h}$ in $1 \mathrm{ml}$ Krebs-Ringer buffer containing $119 \mathrm{mM} \mathrm{NaCl}, 4.74 \mathrm{mM} \mathrm{KCl}, 2.54$ $\mathrm{mM} \mathrm{CaCl}_{2}, 1.19 \mathrm{mM} \mathrm{MgSO}_{4}, 1.19 \mathrm{mM} \mathrm{KH}_{2} \mathrm{PO}_{4}, 25 \mathrm{mM} \mathrm{NaHCO}$ with $10 \mathrm{mM}$ Hepes, $0.1 \%$ bovine serum albumin, $\mathrm{pH} 7.4$ in $5 \% \mathrm{CO}_{2} /$ $95 \%$ humidified air, $37^{\circ} \mathrm{C}$. At the end of the incubation period, buffer was removed, centrifuged briefly, and the supernatant frozen at $-20^{\circ} \mathrm{C}$ for insulin assay (26). For measurement of cellular insulin content, HIT cells were rinsed twice with $1 \mathrm{ml}$ phosphate buffered saline, scraped in $1 \mathrm{ml}$ phosphate buffered saline, homogenized by ultrasonic 
disintegration at $4^{\circ} \mathrm{C}$, and the homogenate assayed for insulin. Protein was determined by the method of Lowry. FK506 was dissolved in ethanol at a stock concentration of $1 \mathrm{mM}$ and stored in the dark at $4^{\circ} \mathrm{C}$.

Insulin $m R N A$ analysis. HIT cells, $5 \times 10^{6}$ cells/dish, were cultured in 60-mm dishes for $96 \mathrm{~h}$ in $5 \mathrm{ml}$ culture media supplemented with vehicle only or FK506 at various concentrations. Media was changed daily. Total HIT cell RNA was isolated by guanidine isothiocyanate/phenol extraction as previously described (7). Insulin mRNA was quantified by slot-blot analysis using the method of White and Bancroft (27). Briefly, total HIT cell RNA was denatured in $12 \times$ SSC, $14.8 \%$ formaldehyde at $65^{\circ} \mathrm{C}$ for $5 \mathrm{~min}$. Total RNA, $2.5-10 \mu \mathrm{g} /$ slot, was then applied to a nylon hybridization membrane and prehybridized overnight at $42^{\circ} \mathrm{C}$ in $50 \%$ formamide, $5 \times$ SSC, $5 \times$ Denhardt's solution, $50 \mathrm{mM}$ sodium phosphate ( $\mathrm{pH}$ 6.5), 0.1\% SDS and $0.1 \mathrm{mg} / \mathrm{ml}$ denatured salmon sperm DNA. ${ }^{32} \mathrm{P}$-labeled cDNA for Syrian hamster preproinsulin was added and hybridized overnight at $42^{\circ} \mathrm{C}$. The membrane was washed in $2 \times \mathrm{SSC}, 0.1 \%$ SDS three times for $10 \mathrm{~min}$ at room temperature and in $0.2 \times \mathrm{SSC}, 0.1 \%$ SDS two times at $65^{\circ} \mathrm{C}$ for $30 \mathrm{~min}$. The membrane was exposed to X-ray film overnight at $-70^{\circ} \mathrm{C}$ with intensifying screens. An identical membrane was hybridized with ${ }^{32} \mathrm{P}$-labeled cDNA for human $\beta$ actin as a control (27). Insulin and $\beta$ actin mRNA levels were quantified from autoradiograms by computer-assisted videodensitometry. Results are expressed as a densitometric ratio of insulin mRNA/ $\beta$ actin mRNA. The Syrian hamster cDNA probe was a gift of Dr. G.I. Bell, Howard Hughes Research Institute, University of Chicago (Chicago, IL) and the $\beta$ actin cDNA probe was a gift of Dr. L. Kedes, University of Southern California School of Medicine (Los Angeles, CA).

Cell transfection experiments. HIT cells, $1.8 \times 10^{6}$ cells $/ 35 \mathrm{~mm}$ well, were plated in $3 \mathrm{ml}$ culture media supplemented with vehicle only or FK506 and cultured for $96 \mathrm{~h}$ with daily media changes. After the initial $72 \mathrm{~h}$ culture, cells were transiently transfected with a human insulin promoter-chloramphenicol acetyl transferase $(\mathrm{CAT})^{1}$ reporter gene via liposome-mediated transfection as previously described (9). This reporter gene contains 327 bp of the $5^{\prime}$-flanking region and $30 \mathrm{bp}$ of exon 1 of the human insulin gene inserted directly upstream of the CAT reporter gene in a promoterless plasmid, pCAT(An) (9). Cells were transfected with $1 \mu \mathrm{g} /$ well reporter gene plasmid in $4 \mu \mathrm{g} /$ well of Lipofectin reagent (Gibco BRL, Gaithersburg, MD). After an additional $24 \mathrm{~h}$ culture, HIT cell extracts were prepared and assayed for CAT enzyme activity (9). In some experiments, HIT cells were cultured in media containing low $(0.4 \mathrm{mM})$ glucose for $24 \mathrm{~h}$ before transfection. Cells were then transfected with the insulin-CAT reporter gene and cultured for an additional $24 \mathrm{~h}$ in culture media with either 0.4 or $20 \mathrm{mM}$ glucose supplemented with either vehicle or FK506. Cell extracts were then prepared and assayed as before. As a control for nonspecific effects of FK506 on reporter gene activity, separate wells of HIT cells were also transfected with plasmid $(10 \mu \mathrm{g} / \mathrm{well})$ containing the nontissue specific herpes virus thymidine kinase promoter linked to the CAT gene (TKCAT) (28).

Electrophoretic mobility shift assays. HIT cells were exposed to vehicle or $10^{-7} \mathrm{M} \mathrm{FK} 506$ for $24 \mathrm{~h}$ and nuclear extracts were prepared (29). Electrophoretic mobility shift assays were carried out to measure binding activity of nuclear extracts with double stranded oligonucleotide probes to the human insulin A3 (-230 to -201), CRE/ CAAT (-194 to -165$)$, A2 (GGI, -142 to -122$)$, GGII (-153 to -124$)$, and A5/core enhancer (-322 to -296) elements, and the rat insulin II C1 (-126 to -101) and rat insulin E1 (-104 to -85) binding sites as previously described $(30,31)$.

Detection of calcineurin subunits in HIT cells. HIT cell extracts were prepared by suspending HIT cells $\left(\sim 2 \times 10^{6}\right.$ cells $)$ in $80 \mu$ l of cell lysis buffer: $50 \mathrm{mM}$ Tris-HCl, pH 7.4; $1 \% \mathrm{NP}-40 ; 0.25 \%$ sodium deoxycholate; $150 \mathrm{mM} \mathrm{NaCl} ; 1 \mathrm{mM}$ EGTA; $1 \mathrm{mM}$ phenylmethylsul-

1. Abbreviations used in this paper: CAT, chloramphenicol acetyl transferase; Fisher's PLSD, protected least squares difference. fonylfluoride; $1 \mathrm{mM}$ sodium fluoride, and $1 \mu \mathrm{g} / \mathrm{ml}$ aprotinin, leupeptin and pepstatin. After addition of $20 \mu \mathrm{l}$ of loading buffer $(312.5 \mathrm{mM}$ Tris- $\mathrm{HCl}, \mathrm{pH} 6.8,10 \%$ SDS, $25 \%$-mercaptoethanol and $50 \%$ glycerol) extracts were boiled for $5 \mathrm{~min}$ and proteins separated by SDSPAGE through a $12 \%$ acrylamide gel. Approximately $300 \mu \mathrm{g}$ of protein was applied to each lane. Proteins were transferred to Immobilon P membranes (Millipore Corp., Bedford, MA) by semi-dry transfer and then subjected to Western analysis.

For immunoblotting, membranes were blocked as previously described (32). Polyclonal bovine brain calcineurin antiserum (Upstate Biotechnology Inc., Lake Placid, NY) was used at $1 \mu \mathrm{g} / \mathrm{ml}$. Immunoreactivity was detected by applying a horseradish peroxidase-conjugated $\mathrm{F}\left(\mathrm{ab}^{\prime}\right)_{2}$ (BioRad Laboratories, Hercules, CA) and then adding a chemiluminescent substrate (Pierce Corp., Rockford, IL). After adding the chemiluminescent substrate, the membranes were exposed to X-OMAT AR X-ray film for various times ranging from 1 to 20 min. Purified bovine brain calcineurin (Sigma Chemical Co., St. Louis, MO) was included as a control.

Statistical analysis. Differences between vehicle and FK506 treatment were compared using Student's $t$ test for unpaired data, or, in the case of dose-response experiments, ANOVA using a one-factor model followed by Fisher's protected least squares difference (PLSD) for comparison between treatments. Data are presented as means \pm SE.

\section{Results}

Lack of acute effect of FK506 on insulin secretion. To determine whether FK506 or the ethanol vehicle might have a direct, acute effect to alter insulin secretion, HIT cells grown in RPMI-1640 in the absence of any drug were acutely exposed to increasing concentrations of FK506 in 4-h static incubation experiments. In the presence of $11.1 \mathrm{mM}$ glucose, HIT cell insulin secretion increased fivefold over basal (absence of glucose) in 4-h static incubations $(740 \pm 170$ vs $3,810 \pm 647 \mu \mathrm{U}$ insulin/mg protein, $P \leq 0.01)$. FK506 at increasing concentrations up to $1 \mu \mathrm{M}$ had no effect on glucose stimulation of insulin release in these acute experiments (insulin secretion in the presence of $1 \mu \mathrm{M}$ FK506: 4,100 $\pm 680 \mu \mathrm{U} / \mathrm{mg}$ protein).

Effect of more prolonged exposure to FK506 on insulin secretion and cellular insulin content. To determine whether more prolonged exposure to FK506 might alter HIT cell insulin release, HIT cells were cultured for $72 \mathrm{~h}$ in the presence of vehicle or FK506 at increasing concentrations from $10^{-9}$ to $10^{-6} \mathrm{M}$. HIT cell media was changed every $24 \mathrm{~h}$ and insulin secretion into the media over the preceding $24 \mathrm{~h}$ was measured. At the end of the experiment, intracellular insulin content was also measured. FK506 had no significant effect on media insulin levels during the initial $24 \mathrm{~h}$ of exposure (Fig. 1). However, between $24-48 \mathrm{~h}$ there was a significant dose-dependent effect of FK506 on media insulin levels $(P \leq 0.002$, ANOVA, $n=3)$. There was a further decrease in media insulin levels during the 48-72 $\mathrm{h}$ exposure period $(P \leq 0.0001$, ANOVA). The maximal decrease in HIT cell insulin release occurred at $10^{-7}$ M FK506 and was $57 \pm 3 \%$ of control levels after $72 \mathrm{~h}$ exposure. Subsequent experiments in which HIT cells were chronically cultured up to 4 wk in FK506 revealed no further decrease in insulin release (data not shown). Thus the inhibitory effect of FK506 appeared to be maximal after $72 \mathrm{~h}$ exposure.

Intracellular insulin content was also significantly decreased in a dose-dependent manner following $72 \mathrm{~h}$ exposure to FK506 (Fig. 2). The decrease in insulin content paralleled the decrease in insulin release and represented a $35-40 \%$ decrease in insulin content relative to control levels. FK506 had 


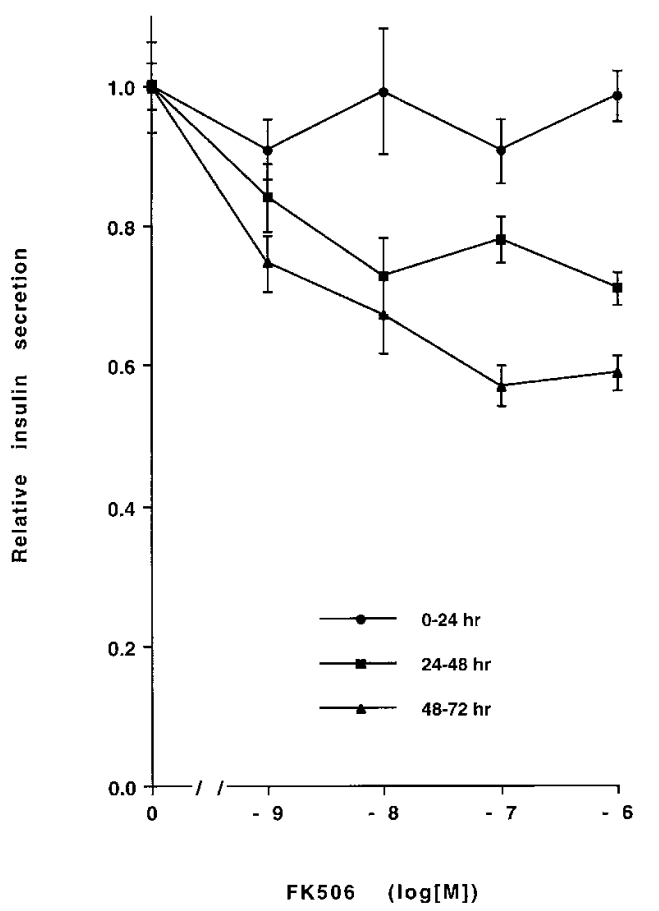

Figure 1. Time- and dose-dependent effect of FK506 on HIT cell insulin secretion. HIT cells were cultured for up to $72 \mathrm{~h}$ in the presence of vehicle or increasing concentrations of FK506. HIT cell media were replaced every $24 \mathrm{~h}$ and insulin secretion was measured in the media. There was a significant time- and dose-dependent effect of FK506 to reduce insulin secretion into HIT cell media first apparent during the $24-48 \mathrm{~h}$ exposure period $(P \leq 0.002$ for FK506 effect, ANOVA, $n=3)$. The decrease in media insulin levels was even greater during the $48-72 \mathrm{~h}$ exposure period ( $P \leq 0.0001$, ANOVA). Media insulin levels were significantly less than control at every FK506 concentration during the $24-48 \mathrm{~h}$ and $48-72 \mathrm{~h}$ exposure periods $(P \leq 0.05$, Fisher's PLSD $)$.

no effect on HIT cell viability as assessed by HIT cell protein content at the end of $72 \mathrm{~h}$ culture (vehicle only: $0.295 \pm 0.028$, FK506 $10^{-9}$ M: $0.293 \pm 0.032$, FK506 $10^{-7}$ M: 0.269 $\pm 0.037 \mathrm{mg} /$ well).

Reversibility of FK506 effect on insulin secretion. To determine whether the effects of FK506 on insulin secretion were reversible and not simply a toxic effect of the drug on cell function or viability, duplicate sets of HIT cells were cultured for $72 \mathrm{~h}$ in media supplemented with either vehicle or FK506 (1 $\mu \mathrm{M})$. After $72 \mathrm{~h}$, one set of HIT cells was washed to remove any drug and static incubation experiments were performed in the absence of FK506 or vehicle. For the second set of HIT cells, media was changed and cells were cultured an additional $72 \mathrm{~h}$ in the absence of FK506. Static incubation experiments were then carried out as before. As shown in Fig. 3, HIT cells cultured for $72 \mathrm{~h}$ in FK506 showed a 35-40\% decrease in glucoseinduced insulin release during static incubations (Fig. $3 A$ ). However, this effect was completely reversed after an additional 72-h culture in the absence of drug (Fig. $3 B$ ).

Effect of FK506 on levels of HIT cell insulin mRNA. To determine whether FK506 might impair insulin synthesis via effects on insulin mRNA levels, insulin and $\beta$ actin mRNA levels were quantitated by slot-blot analysis of total HIT cell RNA from cells cultured for $96 \mathrm{~h}$ in media supplemented with vari-

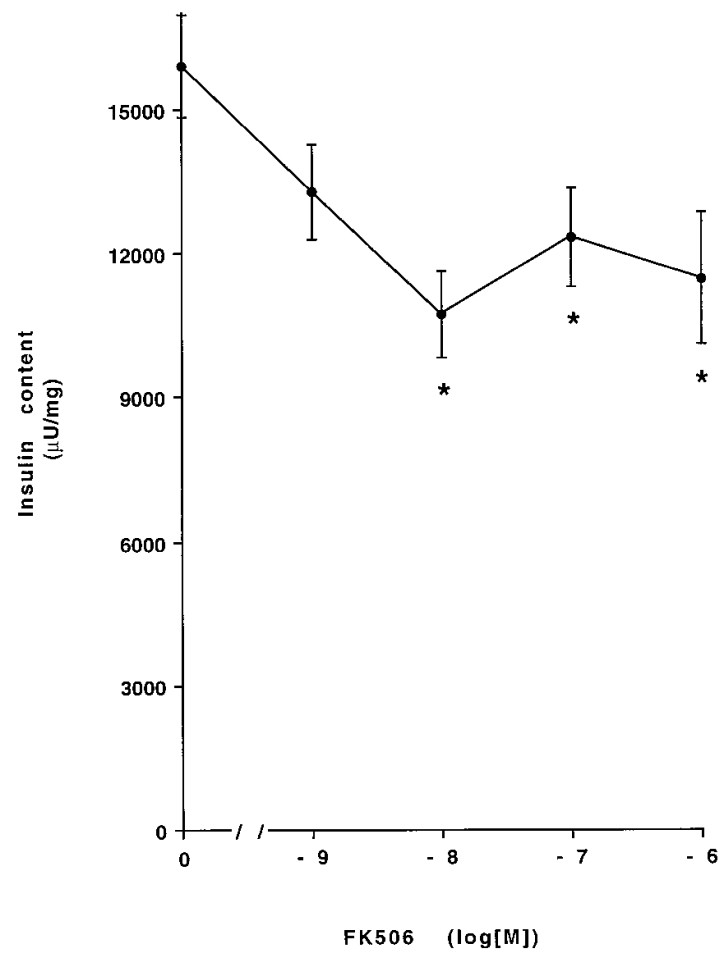

Figure 2. Effect of FK506 on HIT cell insulin content. At the end of the experimental period described in Fig. 1, HIT cell insulin content was measured as described in Methods. Intracellular insulin content was significantly decreased in a dose-dependent manner in the presence of FK506 ( $P \leq 0.05$, ANOVA). $* P \leq 0.05$ vs control, Fisher's PLSD.

ous concentrations of FK506. Insulin secretion into the culture media was also measured over the final $24 \mathrm{~h}$ of culture. Insulin secretion and insulin mRNA both significantly decreased in the presence of increasing concentrations of FK506 $\left(10^{-9}\right.$ to $\left.10^{-7} \mathrm{M}\right)(P \leq 0.001, n=6$ for both secretion and mRNA level $)$ (Fig. 4). FK506 at $10^{-7} \mathrm{M}$ reduced both insulin secretion and insulin mRNA levels by $\sim 45 \%$.

Effect of FK506 on HIT cell expression of human insulinCAT reporter gene. To determine whether FK506 might lower HIT cell levels of insulin mRNA by inhibiting transcription of the insulin gene, we studied the effect of FK506 on HIT cell expression of a human insulin-CAT reporter gene in transient transfection experiments. We have previously reported that HIT cell expression of this insulin promoter-driven construct is glucose-responsive and correlates with changes in HIT cell mRNA levels in a variety of experimental conditions $(9,33)$. In the current studies, HIT cells were cultured for $72 \mathrm{~h}$ in media supplemented with vehicle or FK506. HIT cells were then transfected with the human insulin-CAT reporter gene using a liposome technique. After an additional $24 \mathrm{~h}$ culture, culture media was sampled for insulin secretion and CAT activity was measured in HIT cell extracts. Both insulin secretion into the culture media and CAT activity in HIT cell extracts decreased significantly ( $P \leq 0.02$ and $P \leq 0.01$, respectively, $n=8)$ and in a dose-dependent manner in response to increasing concentrations of FK506 (Fig. 5). FK506 at $10^{-7} \mathrm{M}$ reduced insulin secretin by $40 \%$ and insulin-CAT reporter gene expression by $30 \%$.

HIT cell expression of the human insulin-CAT reporter 

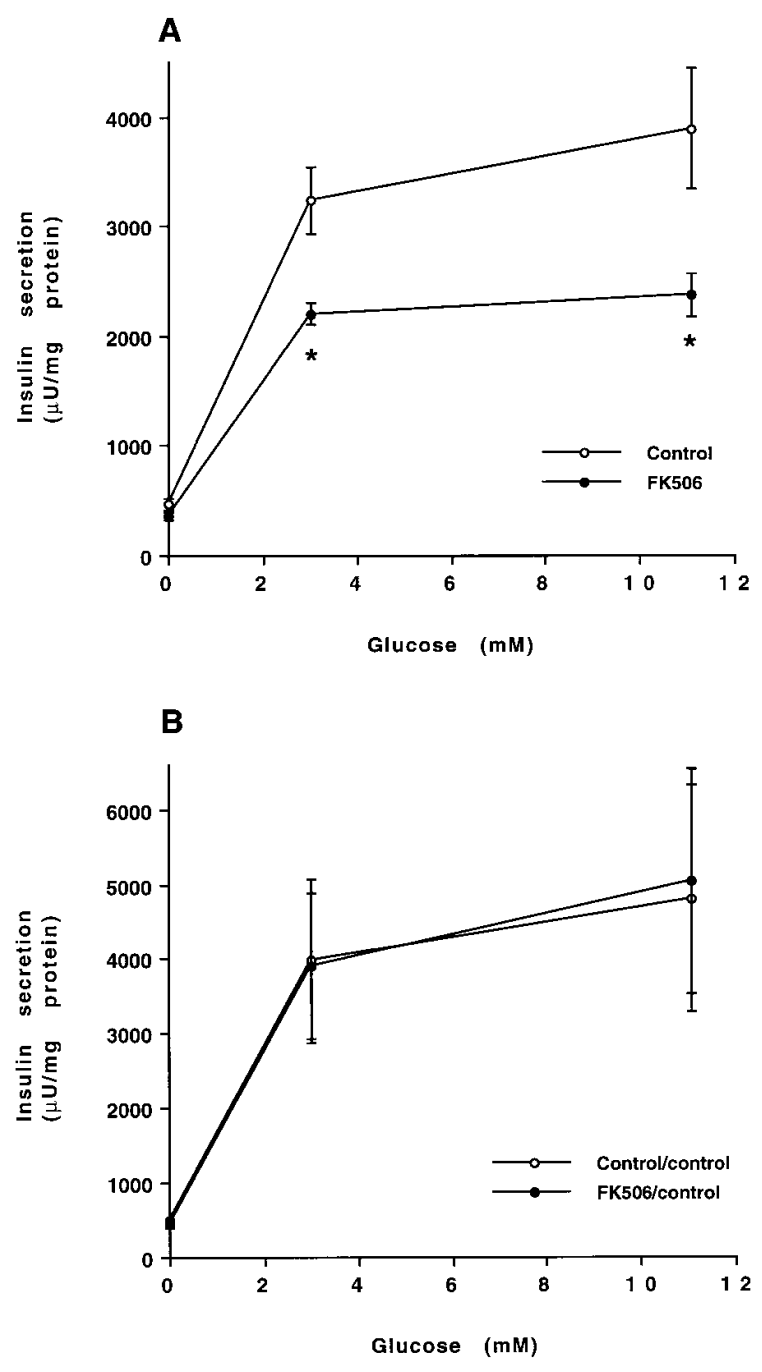

Figure 3. Effect of FK506 on insulin secretion is reversible. Duplicate sets of HIT cells were cultured for $72 \mathrm{~h}$ in $1 \mu \mathrm{M}$ FK506 or vehicle. $(A)$ After $72 \mathrm{~h}$, cells were washed to remove any drug or vehicle and 4-h static incubation experiments were carried out with one set of HIT cells at 0,3 and $11.1 \mathrm{mM}$ glucose as described in Methods. $\left({ }^{*} P<0.05\right.$ vs control, $n=3$ ). (B) In the duplicate set of HIT cells, following the initial $72 \mathrm{~h}$ exposure to FK506 the media was changed and the cells were cultured an additional $72 \mathrm{~h}$ in media in the absence of drug. After this wash-out period, 4-h static incubation experiments were repeated as before. The inhibitory effect of FK506 on insulin secretion was completely reversed in these cells.

gene in the presence of high and low glucose levels was also assessed after short-term $(24 \mathrm{~h})$ exposure to drug. In these experiments, HIT cells were first cultured in media with low glucose $(0.4 \mathrm{mM})$ concentration for $24 \mathrm{~h}$ before the transfection period. Cells were then transfected in the presence of vehicle or FK506 $\left(10^{-7} \mathrm{M}\right)$ in media with either 0.4 or $20 \mathrm{mM}$ glucose to determine whether FK506 would block the normal glucoseinduced increase in reporter gene expression. As shown in Fig. 6, when exposed to $20 \mathrm{mM}$ glucose HIT cell expression of the human insulin-CAT reporter gene increased threefold relative to the basal condition ( $0.4 \mathrm{mM}$ glucose). FK506 inhibited human insulin-CAT reporter gene expression by $40 \%$ under conditions of both high and low glucose concentrations. FK506

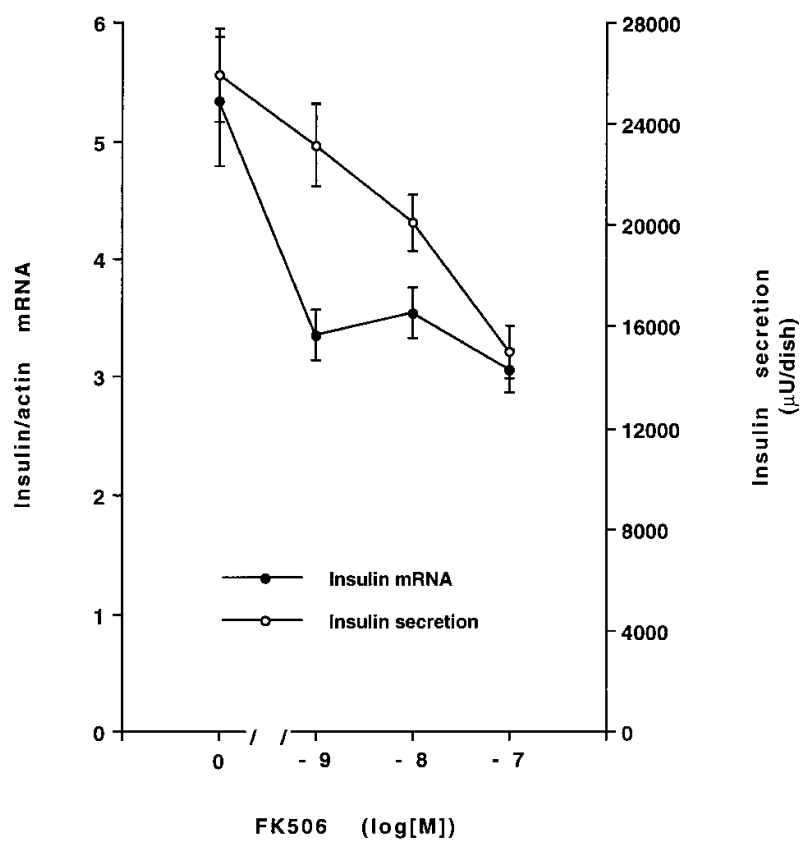

Figure 4. Effect of FK506 on HIT cell insulin mRNA levels. HIT cells were cultured for $96 \mathrm{~h}$ in vehicle or increasing concentrations of FK506. Total HIT cell mRNA was extracted and insulin and $\beta$ actin mRNA levels were determined by Northern slot-blot analysis with computer-assisted videodensitometry. Data are expressed as ratio of insulin/actin mRNA. Insulin secretion into the HIT cell media was also determined over the final $24 \mathrm{~h}$ of culture. $(P \leq 0.001$ for FK506 effect on both insulin mRNA and insulin secretion, ANOVA, $n=6$ ).

had no significant effect on HIT cell expression of the control reporter gene TKCAT (relative TKCAT expression: 1.0 \pm 0.2 vs $0.8 \pm 0.2$, control vs FK506, $n=3, P=0.44$ ).

It is well established that insulin promoter activity requires the interactions of trans-acting factors to their cis-regulatory binding sites. Best characterized of these interactions include the binding of STF-1, the RIPE 3b1 activator, and the ICE activator to the A1 and A3 elements, $\mathrm{C} 1$ element, and E1 and E2 elements, respectively. To determine whether FK506 might alter binding of trans-activating factors to their respective insulin promoter sequences we performed electrophoretic mobility shift assays using DNA probes corresponding to the human A3 element (-230/-201), rat insulin II C1 element (-126/-101), and rat insulin II E1 element (-104/-85). In addition, we examined whether FK506 might alter binding to the human insulin gene CRE/CAAT element (-194/-165), human A2 element (GGI, -142/-122), human GGII element (-153/-124), human A5/core enhancer elements (-322/-296). Nuclear extracts isolated from HIT cells cultured for $24 \mathrm{~h}$ in the presence of vehicle or FK506 showed no alterations in binding activities to any of these elements (data not shown).

Detection of calcineurin in HIT cells. To determine whether calcineurin is present in the HIT cell, Western blot analysis of HIT cell proteins was performed using an antibody raised against bovine brain calcineurin (Fig. 7). In HIT cell extracts, this antibody detected bands corresponding to both the calcineurin A (61 kD) and calcineurin B (19 kD) subunits which make up the calcineurin heterodimer (Fig. 7) (34). 


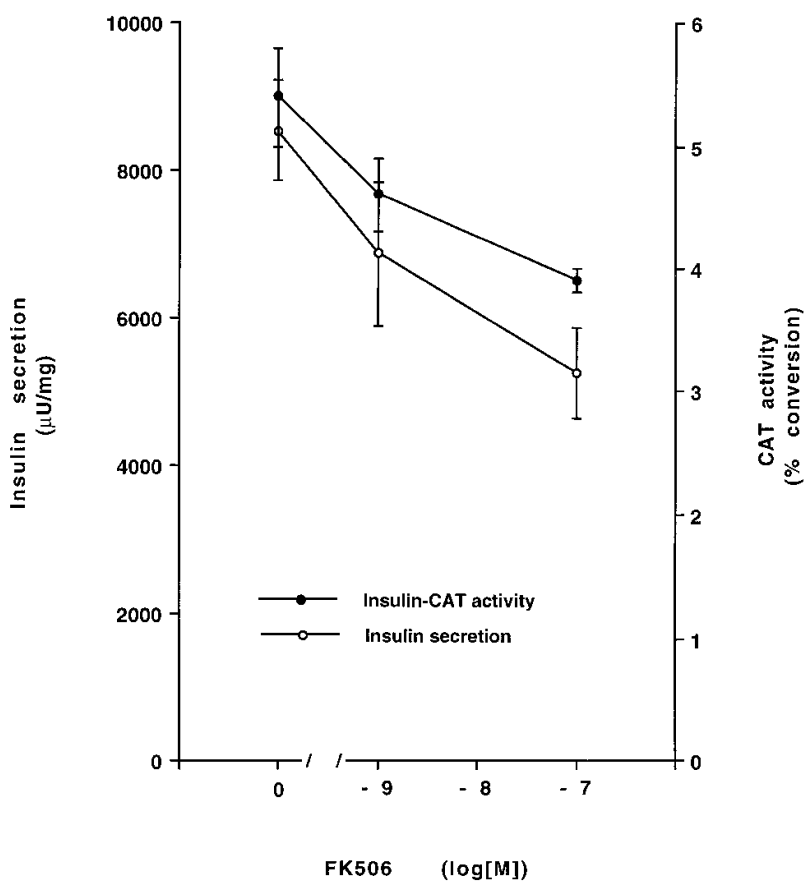

Figure 5. Effect of FK506 on HIT cell expression of human insulinCAT reporter gene. HIT cells were cultured for $96 \mathrm{~h}$ in vehicle, 1 or $100 \mathrm{nM}$ FK506. During the final $24 \mathrm{~h}$ of culture, HIT cells were transfected with a human insulin-CAT reporter gene as described in Methods. After $24 \mathrm{~h}, \mathrm{CAT}$ activity (percent conversion $\left[{ }^{14} \mathrm{C}\right]$ chloramphenicol to acetylated $\left[{ }^{14} \mathrm{C}\right]$ chloramphenicol) was measured in HIT cell extracts. Insulin secretion into the culture media was also measured over the final $24 \mathrm{~h}$ of the experiment. There was a significant effect of FK506 on both human insulin-CAT reporter gene expression $(P \leq$ $0.01)$ and insulin secretion $(P \leq 0.02)$, ANOVA, $n=8$.

\section{Discussion}

FK506 is a drug known to inhibit $\mathrm{Ca}^{2+}$-mediated stimulation of gene expression in T cells and is also a drug associated with hyperglycemia and diabetes mellitus in clinical studies. The purpose of this study was to determine whether FK506 might have inhibitory effects on insulin gene expression in the $\beta$ cell which would then lead to decreased insulin synthesis and secretion. Using the HIT cell model, we observed a reversible, time- and dose-dependent effect of FK506 to lower insulin secretion. Decreased insulin secretion was accompanied by a decline in HIT cell insulin content and insulin mRNA levels when cells were cultured in the presence of FK506, suggesting that FK506 decreased insulin synthesis through effects at the level of insulin gene transcription or posttranscriptional processing. In transient transfection experiments, we found that FK506 produced a rapid, dose-dependent inhibition of HIT cell expression of a human insulin promoter-CAT reporter gene. FK506 inhibition of human insulin reporter gene expression was apparent within $24 \mathrm{~h}$ of exposure of HIT cells to the drug and preceded any measurable effect of FK506 on insulin secretion. These data suggest that FK506 lowers HIT cell insulin mRNA levels, at least in part, through inhibitory effects on insulin gene transcription.

The observed effect of FK506 to decrease insulin secretion does not appear to be due to a direct action of the drug to inhibit insulin release, nor to a toxic effect of the drug on cell

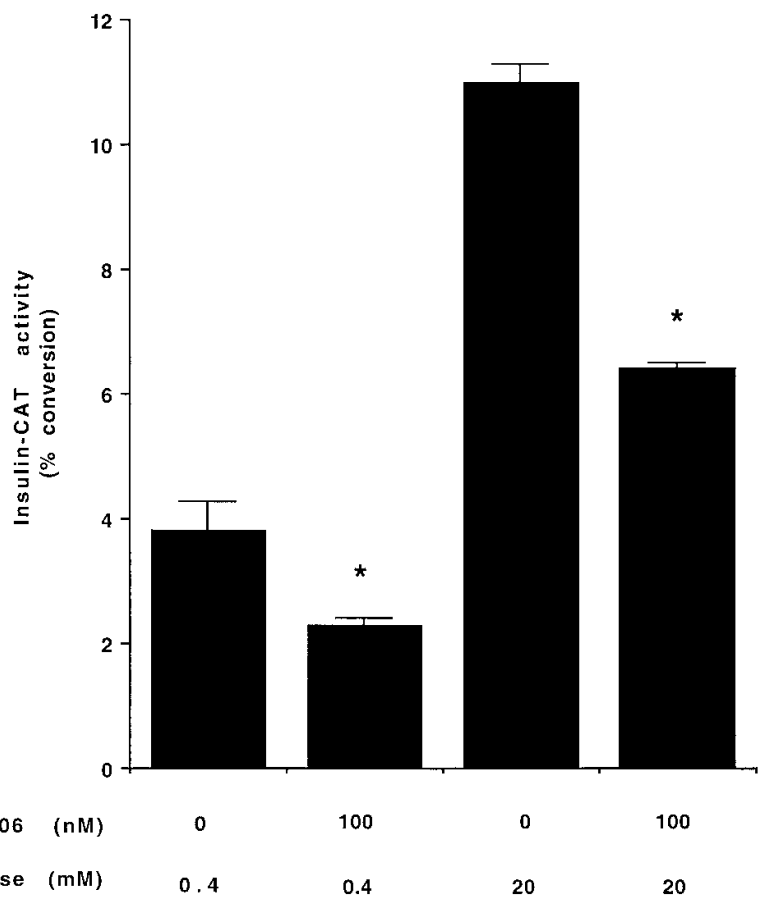

Figure 6. Effect of FK506 on HIT cell expression of human insulinCAT reporter gene during 24-h exposure. HIT cells were cultured in low $(0.4 \mathrm{mM})$ glucose media for $24 \mathrm{~h}$, then cultured in 0.4 or $20 \mathrm{mM}$ glucose during subsequent $24 \mathrm{~h}$ transfection experiments conducted in the presence of vehicle or $10^{-7} \mathrm{M}$ FK506. Human insulin-CAT reporter gene expression increased threefold in response to high glucose. FK506 significantly inhibited human insulin-CAT reporter gene expression by $40 \%$ under both high $(20 \mathrm{mM})$ and low $(0.4 \mathrm{mM})$ glucose conditions $(* P \leq 0.05$, vehicle vs FK506, $n=3)$.

growth or function. Acute administration of the drug in static incubation experiments in doses up to $1 \mu \mathrm{M}$ had no effect on insulin secretion in response to glucose. More prolonged cell culture in the presence of drug for $48-72 \mathrm{~h}$ was required before the full effects of the drug on insulin secretion became apparent. Prolonged culture of HIT cells in FK506 had no effect on cell growth or viability as assessed by protein content. Moreover, the inhibitory effect of FK506 on insulin secretion was fully reversible when HIT cells were cultured in the absence of drug.

The half-life of insulin mRNA has been estimated to be $\sim 30 \mathrm{~h}$ in both the HIT cell and primary islet cultures $(8,35)$. Thus, the time dependence of the FK506 effect on insulin secretion and insulin mRNA levels would be consistent with an action of the drug at the level of insulin gene expression. The transient transfection experiments suggest FK506 directly decreases the rate of insulin gene transcription, although it is possible the drug may have additional effects to lower insulin mRNA such as altering the rate of insulin mRNA metabolism.

Both FK506 and cyclosporin A have been associated with decreased glucose tolerance following solid organ transplantation (19-22, 36-39). Several recent randomized trials comparing these two drugs suggest hyperglycemia may occur more frequently in patients treated with FK506 (36-39). In general, hyperglycemia associated with FK506 appears to be dose related and reversible $(20,36,39,40)$. The majority of studies that have examined the hyperglycemic effects of FK506 sug- 


\section{$\alpha$ subunit}

\section{B subunit}
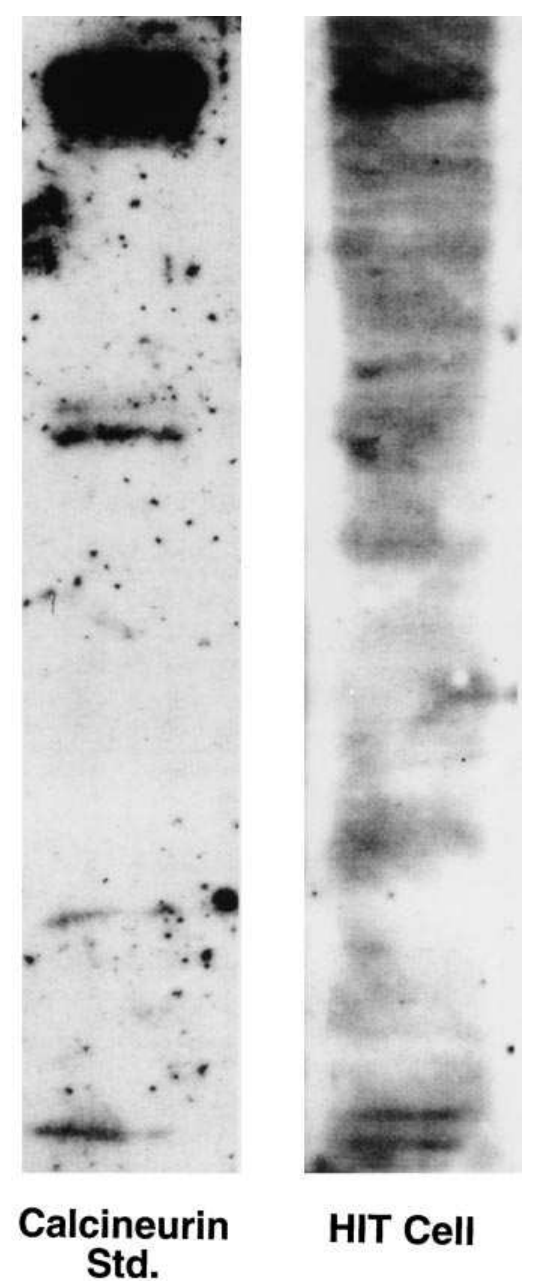

HIT Cell

Figure 7. Detection of calcineurin in HIT cells. Purified bovine brain calcineurin standard (lane 1) and HIT cell extract (lane 2) were resolved by SDS-PAGE using a $12 \%$ acrylamide gel. Western blot analysis was performed with polyclonal rabbit anti-bovine brain calcineurin antibody. HIT cell extracts contained immunoreactivity corresponding to the calcineurin $\alpha(61 \mathrm{kD})$ and $\beta(19 \mathrm{kD})$ subunits, respectively.

gest the drug acts at the level of the islet to decrease insulin secretion, although alterations in peripheral insulin sensitivity may also play a role (37). FK506 has been shown to decrease glucose-induced insulin secretion in both intact animals as well as isolated islet and perfused pancreas preparations (40-43).

Few studies have attempted to define the time course of the FK506 effect or identify the site of action of the drug within the $\beta$ cell. Carroll et al. (44) reported an acute effect of FK506 at high concentrations $(>100 \mathrm{nM})$ to inhibit insulin secretion from isolated rat islets. There was little effect of the drug at lower concentrations during 24-h culture experiments. Herold et al. examined the effect of cyclosporin A and an FK506 analog, L-683,590, on glucose-induced insulin secretion in the $\beta$ TC3 mouse islet tumor line and in rat islets (23). Similar to our results with FK506, these investigators found no acute effect of either drug on insulin secretion; rather, significant effects on insulin secretion were seen only after prolonged (48 h) exposure. As was the case in our studies with FK506, both drugs also decreased insulin mRNA levels in $\beta$ TC 3 cells.

Recently, Tamura et al. reported a reversible decrease in insulin mRNA levels in islets isolated from rats treated for 14 days with FK506 (24). Although the dose of FK506 used in these studies $(10 \mathrm{mg} / \mathrm{kg}$ per $\mathrm{d})$ has previously been reported to produce histologic changes suggestive of islet toxicity (42), the findings of Tamura et al. are consistent with the observations of Herold et al. and our own findings reported here $(23,24)$.

We are unaware of previous studies that have investigated the effect of FK506 on insulin gene transcription. Our studies were prompted by the observation that a major mechanism of action of both FK506 and cyclosporin A is inhibition of $\mathrm{Ca}^{2+}$ mediated activation of specific T cell genes (15-17). This inhibition of gene expression appears to depend on the ability of these drugs to bind to endogenous cellular proteins (immunophilins) and to inactivate a $\mathrm{Ca}^{2+} /$ calmodulin-dependent protein phosphatase, calcineurin. While elucidation of this novel intracellular $\mathrm{Ca}^{2+}$-mediated signaling pathway was primarily carried out in T cells, it is now known that the immunophilins are ubiquitous proteins and that calcineurin is present in a variety of tissues, including the pancreatic islet (45) and the HIT cell (current study). Recent studies in renal tubular cells and PC12 cells, a neuroendocrine cell line, suggest a role for $\mathrm{Ca}^{2+}$ mediated regulation of gene transcription via the $\mathrm{Ca}^{2+} / \mathrm{cal}-$ modulin/calcineurin pathway in these nonimmune cells $(46,47)$. Schwaninger et al. reported that potassium-induced membrane depolarization stimulated $\mathrm{Ca}^{2+}$-mediated transcription of the glucagon gene via a cAMP-responsive element (48). This transcriptional activation involved calcineurin phosphatase activity and was inhibited by both FK506 and cyclosporin A. Thus, it appears likely that the $\mathrm{Ca}^{2+} /$ calmodulin/calcineurin pathway first identified in the $\mathrm{T}$ cell may be an important pathway for $\mathrm{Ca}^{2+}$-mediated regulation of gene transcription in a wide variety of cell types.

In our studies, inhibition of insulin promoter-CAT reporter gene expression by FK506 correlated with decreased insulin mRNA levels and ultimately decreased insulin secretion. This is consistent with both in vitro and in vivo studies demonstrating that in the steady-state, insulin biosynthesis and secretion are predominantly determined by levels of insulin mRNA (1). Thus in the $\beta$ cell, insulin synthesis and secretion appear to be coordinately regulated events. Since insulin secretion is a $\mathrm{Ca}^{2+}$-dependent event, it would certainly be plausible that regulation of insulin gene transcription may involve $\mathrm{Ca}^{2+}$-mediated mechanisms. One such mechanism may involve a $\beta$ cell $\mathrm{Ca}^{2+} /$ calmodulin/calcineurin pathway.

$\mathrm{Ca}^{2+}$-mediated regulation of gene transcription may involve multiple mechanisms within a given cell via activation of calmodulin-dependent kinases and phosphatases (47, 49). Regulation of insulin gene expression may also involve other cellular pathways such as the adenylate cyclase/cAMP or phosphoinositide/protein kinase $\mathrm{C}$ second messenger systems (1, 13, 14). At the molecular level, multiple cis-acting DNA sequences in the insulin promoter and trans-acting nuclear proteins have been implicated in both $\beta$ cell specific and glucoseinducible regulation of insulin gene expression $(1,2,11)$. Thus it is likely that multiple mechanisms are involved in regulation of insulin gene expression.

In summary, we have demonstrated in a glucose-responsive, insulin-secreting $\beta$ cell line that FK506 decreases insulin secretion in a reversible, time- and dose-dependent manner which correlates with inhibitory effects of the drug on human insulin gene expression. These data suggest a possible explana- 
tion for the diabetogenic effects associated with the clinical use of this drug. FK506 and related drugs may also prove to be valuable tools in further defining the cellular pathways that transmit the glucose metabolic signal to the $\beta$ cell nucleus to regulate insulin gene expression and insulin biosynthesis.

\section{Acknowledgments}

FK506 was a gift of the Fujisawa Pharmaceutical Co., Ltd. We wish to thank Dr. Daniel Weisdorf and Dr. Howard C. Towle for valuable advice and assistance. We thank Ms. Elizabeth Oseid and Ms. Jennifer Burkhart for technical and secretarial assistance.

This work was supported by National Institute of Health grants K08-DK02134 (J.B. Redmon) and R01-DK38325 (R.P. Robertson).

\section{References}

1. Philippe, J. 1991. Structure and pancreatic expression of the insulin and glucagon genes. Endocr. Rev. 12:252-271.

2. Docherty, K., A.R. Clark, V. Scott, and S.W. Knight. 1991. Metabolic control of insulin gene expression and biosynthesis. Proc. Nutr. Soc. 50:553-558.

3. Permutt, M.A., and D.M. Kipnis. 1972. Insulin Biosynthesis: I. On the mechanism of glucose stimulation. J. Biol. Chem. 247:1194-1199.

4. Brunstedt, J., and S.J. Chan. 1982. Direct effect of glucose on the preproinsulin mRNA level in isolated pancreatic islets. Biochem. Biophys. Res. Commun. 106:1383-1389.

5. Nielsen, D.A., M. Welsh, J. Casadaban, and D.F. Steiner. 1985. Control of insulin gene expression in pancreatic $\beta$-cells and in an insulin-producing cell line, RIN-5F cells. I. Effects of glucose and cAMP on the transcription of insulin mRNA. J. Biol. Chem. 260:13585-13589.

6. German, M.S., L.G. Moss, and W.J. Rutter. 1990. Regulation of insulin gene expression by glucose and calcium in transfected primary islet cultures. $J$. Biol. Chem. 265:22063-22066.

7. Zhang, H-J., J.B. Redmon, J.M. Andresen, and R.P. Robertson. 1991. Somatostatin and epinephrine decrease insulin messenger ribonucleic acid in HIT cells through a pertussis toxin-sensitive mechanism. Endocrinology. 129:24092414.

8. Philippe, J. 1993. Somatostatin inhibits insulin-gene expression through a posttranscriptional mechanism in a hamster islet cell line. Diabetes. 42:244-249.

9. Redmon, J.B., H.C. Towle, and R.P. Robertson. 1994. Regulation of human insulin gene transcription by glucose, epinephrine, and somatostatin. Diabetes. 43:546-551.

10. Fehmann, H.-C., and J.F. Habener. 1992. Galanin inhibits proinsulin gene expression stimulated by the insulinotropic hormone glucagon-like peptide-I(7-37) in mouse insulinoma $\beta$ TC-1 cells. Endocrinology. 130:2890-2896.

11. Melloul, D., and E. Cerasi. 1994. Transcription of the insulin gene: towards defining the glucose-sensitive cis-element and trans-acting factors. Diabetologia. 37:S3-S10.

12. Efrat, S., M. Surana, and N. Fleischer. 1991. Glucose induces insulin gene transcription in a murine pancreatic $\beta$-cell line. J. Biol. Chem. 266:1114111143.

13. Goodison, S., S. Kenna, and S.J.H. Ashcroft. 1992. Control of insulin gene expression by glucose. Biochem. J. 285:563-568.

14. Welsh, M., T. Weber, O. Wrange, D.A. Nielsen, M. Matthieu, and D.F. Steiner. 1988. Regulation of insulin gene expression by dexamethasone, $\mathrm{Ca}^{2+}$ and a phorbol ester. Biomed. Biochim. Acta. 47:299-303.

15. Sawada, S., G. Suzuki, Y. Kawase, and F. Takaku. 1987. Novel immunosuppressive agent, FK506. In vitro effects on the cloned T cell activation. J. Immunol. 139:1797-1803.

16. Schreiber, S.L. 1991. Chemistry and biology of the immunophilins and their immunosuppressive ligands. Science (Wash. DC). 251:283-287.

17. Liu, J. 1993. FK506 and cyclosporin, molecular probes for studying intracellular signal transduction. Immunol. Today. 14:290-295.

18. O'Keefe, S.J., J. Tamura, R.L. Kincaid, M.J. Tocci, and E.A. O'Neill. 1992. FK-506- and CsA-sensitive activation of the interleukin-2 promoter by calcineurin. Nature (Lond.). 357:692-694.

19. Shapiro, R., M. Jordan, J. Fung, J. McCauley, J. Johnston, Y. Iwaki, A. Tzakis, T. Hakala, S. Todo, and T.E. Starzl. 1991. Kidney transplantation under FK506 immunosuppression. Transplant Proc. 23:920-923.

20. Fung, J.J., M. Alessiana, K. Abu-Elmagd, S. Todo, R. Shapiro, A. Tzakis, D. van Thiel, J. Armitage, A. Jain, J. McCauley, R. Selby, and T.E. Starzl. 1991. Adverse effects associated with the use of FK506. Transplant Proc. 23: 3105-3108.

21. Armitage, J.M., R.L. Kormos, S. Morita, J. Fung, G.C. Marrone, R.L. Hardesty, B.P. Griffith, and T.E. Starzl. 1992. Clinical trial of FK506 immunosuppression in adult cardiac transplantation. Ann. Thorac. Surg. 54:205-211.

22. Odocha, O., J. McCauley, V. Scantlebury, R. Shapiro, P. Carroll, M.
Jordan, C. Vivas, J.J. Fung, and T.E. Starzl. 1993. Posttransplant diabetes mellitus in African Americans after renal transplantation under FK506 immunosuppression. Transplant Proc. 25:2433-2434.

23. Herold, K.C., S. Nagamatsu, J.B. Buse, P. Kulsakdinun, and D.F. Steiner. 1993. Inhibition of glucose-stimulated insulin release from $\beta$ TEC3 cells and rodent islets by an analog of FK506. Transplantation. 55:186-192.

24. Tamura, K., T. Fujimura, T. Tsutsumi, K. Nakamura, T. Ogawa, C. Atumaru, Y. Hirano, K. Ohara, K. Ohtsuka, K. Shimomura, and M. Kobayashi. 1995. Transcriptional inhibition of insulin by FK506 and possible involvement of FK506 binding protein-12 in pancreatic $\beta$-cell. Transplantation. 59:16061613.

25. Santerre, R.F., R.A. Cook, R.M.D. Crisel, J.D. Sharp, R.J. Schmidt D.C. Williams, and C.P. Wilson. 1981. Insulin synthesis in a clonal cell line of Simian virus 40 -transformed hamster pancreatic beta cells. Proc. Natl. Acad. Sci. USA. 78:4339-4443.

26. Morgan, C.R., and A. Lazarow. 1963. Immunoassay of insulin: two antibody system. Plasma insulin levels of normal, subdiabetic and diabetic rats. $\mathrm{Di}$ abetes. 12:115-126.

27. Zhang, H.-J., B. Petersen, and R.P. Robertson. 1994. Variable regulation by insulin of insulin gene expression in HIT-T15 cells. Diabetologia. 37: $559-566$.

28. Jacoby, D.B., N.D. Zilz, and H.C. Towle. 1989. Sequences within the 5 -flanking region of the $\mathrm{S} 14$ gene confer responsiveness to glucose in primary hepatocytes. J. Biol. Chem. 264:17623-17626.

29. Schreiber, E., P. Matthias, M.M. Muller, and W. Schaffner. 1989. Rapid detection of octamer binding proteins with 'mini extracts', prepared from a small number of cells. Nucleic Acids Res. 17:6419.

30. Olson, L.K., A. Sharma, M. Peshavaria, C.V.E. Wright, H.C. Towle, R.P. Robertson, and R. Stein. 1995. Reduction of insulin gene transcription in HIT-T15 $\beta$ cells chronically exposed to a supraphysiologic glucose concentration is associated with loss of STF-1 transcription factor expression. Proc. Natl. Acad. Sci. USA. 92:9127-9131.

31. Sharma, A., L.K. Olson, R.P. Robertson, and R. Stein. 1995. The reduction of insulin gene transcription in HIT-T15 B cells chronically exposed to high glucose concentration is associated with the loss of RIPE3b1 and STF-1 transcription factor expression. Mol. Endocrinol. 9:1127-1133.

32. Seaquist, E.R., A.R. Neal, K.D. Shoger, T.F. Walseth, and R.P. Robertson. 1992. G-proteins and hormonal inhibition of insulin secretion from HITT15 cells and isolated rat islets. Diabetes. 41:1390-1399.

33. Olson, L.K., J.B. Redmon, H.C. Towle, and R.P. Robertson. 1993. Chronic exposure of HIT cells to high glucose concentrations paradoxically decreases insulin gene transcription and alters binding of insulin gene regulatory protein. J. Clin. Invest. 92:514-519.

34. Klee, C.B., M.H. Krinks, A.S. Manahan, G.F. Draetta, and D.L. Newton. 1985. In Advances in Protein Phosphatases. Merlverde, W. and J. Di Salvo, editors., Vol 1. 135-146.

35. Welsh, M., D.A. Nielsen, A.J. MacKrell, and D.F. Steiner. 1985. Control of insulin gene expression in pancreatic $\beta$-cells and in an insulin-producing cell line, RIN-5F cells. II. Regulation of insulin mRNA stability. J. Biol. Chem. 260: $13590-13594$.

36. Scantlebury, V., R. Sharpiro, J. Fung, A. Tzakis, J. McCauley, M. Jordan, C. Jensen, T. Hakala, R. Simmons, and T.E. Starzl. 1991. New onset of diabetes in FK506 vs. cyclosporine-treated kidney transplant recipients. Transplant Proc. 23:3169-3170.

37. Krentz, A.J., B. Dousset, D. Mayer, P. McMaster, J. Buckels, R. Cramb, J.M. Smith, and M. Nattras. 1993. Metabolic effects of cyclosporin A and FK506 in liver transplant recipients. Diabetes. 42:1753-1759.

38. European FK506 Multicentre Liver Study Group. 1994. Randomised trial comparing tacrolimus (FK506) and cyclosporin in prevention of liver allograft rejection. Lancet. 344:423-428.

39. The U.S. Multicenter FK506 Liver Study Group. 1994. A comparison of tacrolimus (FK506) and cyclosporine for immunosuppression in liver transplant. N. Engl. J. Med. 331:1110-1115.

40. Tze, W.J., J. Tai, N. Murase, A. Tzakis, and T.E. Starzl. 1991. Effect of FK506 on glucose metabolism and insulin secretion in normal rats. Transplant Proc. 23:3158-3160.

41. Strasser, S., R. Alejandro, E.T. Shapiro, C. Ricordi, S. Todo, and D.H. Mintz. 1992. Effect of FK506 on insulin secretion in normal dogs. Metab. Clin. Exp. 41:64-67.

42. Hirano, Y., S. Fujihara, K. Ohara, S. Katsuki, and H. Noguchi. 1992 Morphological and functional changes of islets of Langerhans in FK506-treated rats. Transplantation. 53:889-894.

43. Müller, M.K., M. Wojcik, H. Coone, T. Philipp, and M.V. Singer. 1991. Inhibition of insulin release by FK506 and its prevention by rioprostil, a stable prostaglandin E1 analogue. Transplant. Proc. 23:2812-2813.

44. Carroll, P.B., A.C. Boschero, M.-Y. Li, A.G. Tzakis, T.E. Starzl, and I Atwater. 1991. Effect of the immunosuppressant FK506 on glucose-induced insulin secretion from adult rat islets of Langerhans. Transplantation. 51:275-278.

45. Gagliardino, J.J., M.H. Krinks, and E.E. Gagliardino. 1991. Identification of the calmodulin-regulated protein phosphatase, calcineurin, in rat pancreatic islets. Biochim. Biophys. Acta. 1091:370-373.

46. Morris, S.M., D. Kepka-Lenhart, R.L. McGill, N.P. Curthoys, and S. 
Adler. 1992. Specific disruption of renal function and gene transcription by cyclosporin A. J. Biol. Chem. 267:13768-13771.

47. Enslen, H., and T.R. Soderling. 1994. Roles of calmodulin-dependent protein kinases and phosphatase in calcium-dependent transcription of immediate early genes. J. Biol. Chem. 269:20872-20877.

48. Schwaninger, M., R. Blume, E. Oetjen, G. Lux, and W. Knepel. 1993.
Inhibition of cAMP-responsive element-mediated gene transcription by cyclosporin A and FK506 after membrane depolarization. J. Biol. Chem. 268: 23111-23115.

49. Bosser, R., R. Aligué, D. Guerini, N. Agell, E. Carafoli, and O. Bachs. 1993. Calmodulin can modulate protein phosphorylation in rat liver cells nuclei. J. Biol. Chem. 268:15477-15483. 